\title{
Pengaruh Penggunaan Media Pembelajaran Geoboard Terhadap Hasil Belajar Siswa Pada Keliling Dan Luas Bangun Datar Kelas III SD
}

\author{
Ayu Ningrum ${ }^{1}$, Safrida Napitupulu ${ }^{2}$ \\ 1,2 Universitas Muslim Nusantara Al-Washliyah \\ Corresponding Author : nayu5460@gmail.com
}



Kata Kunci

Geoboard Learning Media, Mathematics Learning Outcomes

\section{PENDAHULUAN}

Pendidikan merupakan proses pengembangan kemampuan diri sendiri dan kekuatan individu dalam upaya mempersiapkan peserta didik agar menjadi manusia yang berkualitas. Sekolah memiliki peranan penting untuk mempersiapkan siswa meraih kesuksesan di masa depan, yaitu dengan mengembangkan potensi, baik yang berhubungan dengan mata pelajaran, maupun dengan pengembangan diri pribadi, sosial, dan karier dalam kehidupannya. 
Cybernetics: Journal of Research and Educational Studies

Volume 2 Nomor 4, Oktober 2021

Halaman 103-113

Belajar merupakan suatu proses kegiatan untuk memperoleh informasi dari berbagai sumber, atau kegiatan yang dilakukan untuk mempelajari suatu hal agar mencapai tujuan yang di inginkan dari pengalaman yang di peroleh, sehingga terjadi perubahan perilaku. Kegiatan belajar dapat dilakukan dimana pun, pembelajar tersebut merasa nyaman dan mendukung dalam kegiatan belajar, salah satunya pembelajaran formal yang dilakukan di sekolah.

Sekolah merupakan salah satu lembaga pendidikan formal untuk mencapai tujuan pendidikan nasional. Sebagai mana tercantum dalam undang-undang sistem pendidikan nasional No. 20 Tahun 2003 menyatakan tujuan "pendidikan nasional yaitu untuk mengembangkan potensi peserta didik agar menjadi manusia yang beriman dan bertakwa kepada Tuhan Yang Maha Esa, berakhlak mulia, sehat berilmu, cakap, kreatif, mandiri dan menjadi warga negara yang demokratis serta bertanggungjawab" (Depdiknas, 2003).

Matematika merupakan salah satu komponen dari serangkaian mata pelajaran yang memiliki peranan penting dalam dunia pendidikan. Matematika merupakan bidang yang mendukung perkembangan ilmu pengetahuan dan teknologi.Sundayana (2018). Mata pelajaran matematika perlu diberikan pada tingkatan semua peserta didik mulai dari tingkat sekolah dasar dan sekolah menengah sampai perguruan tinggi. Pada pendidikan sekolah dasar matematika berfungsi sebagai bekal peserta didik untuk mengasah kemampuan berpikir logis, kreatif, inovatif dan analitis. Namun sampai saat ini matematika masih menjadi pelajaran yang dinilai memiliki kesulitan yang tinggi, dianggap membosankan, serta menakutkan sehingga sering dihindari peserta didik.

Pada tingkatan satuan sekolah dasar, aspek-aspek matematika yang dipelajari meliputi aspek bilangan, geometri dan pengukuran serta pengolahan data. Salah satu aspek matematika yang sering kita jumpai dalam kehidupan sehari-hari adalah geometri. Pengenalan konsep geometri sangat penting dipelajari. Hal ini sejalan dengan pendapat yang dikemukakan Mursalin, (2016) Pengenalan geometri di sekolah dasar (SD) mempunyai tujuan dasar untuk memberikan suatu kesempatan kepada peserta didik untuk menganalisis lebih jauh dunia tempat hidupnya, serta memberikan sejak dini landasaan berupa konsep-konsep dasar dan simbol-simbol yang diperlukan untuk studi lebih lanjut. Pemahaman konsep-konsep dasar dan simbol-simbol sangat diperlukan untuk studi lebih lanjut serta sangat berpengaruh pada faktor keberhasilan hasil belajar selanjutnya. Salah satu mata pelajaran yang sangat sulit bagi siswa adalah mata pelajaran matematika, mata pelajaran ini dianggap sulit karena di dalam mata pelajaran ini terdapat angka-angka dan rumus-rumus yang membuat kepala siswa pusing, sehingga banyak di antara siswa yang berpikir bahwa matematika itu menakutkan bagi mereka. Hal tersebut sebenarnya bertolak 
belakang dengan keadaan yang sebenarnya, matematika dapat membentuk pola pikir anak serta dapat meningkatkan kreatifitas anak dalam belajar. Maka dari itu pelajaran matematika sangatlah penting di ajarkan sejak usia dini. Hasil belajar siswa di sekolah sangat dipengaruhi oleh kualitas pembelajaran yang dilaksanakan disekolah, salah satu hal yang menentukan kualitas pembelajaran adalah penggunaan berbagai model pembelajaran dan media pembelajaran yang tepat, model pembelajaran ataupun media pembelajaran yang tepat akan membuat siswa memfokuskan dirinya pada pembelajaran yang sedang berlangsung, ketika siswa sudah fokus dalam pembelajaran maka hasil belajar yang di peroleh akan meningkat sehingga siswa bisa berhasil dalam pembelajaran.

Penggunaan media pembelajaran tentunya memberikan pengaruh terhadap kualitas pembelajaran. Upu \& Minggi (2019) menyatakan bahwa media merupakan alat yang dapat membantu dalam proses belajar mengajar untuk memudahkan siswa memahami konsep pelajaran dari yang bersifat abstrak atau tidak nyata menjadi nyata.

Pemilihan media pembelajaran yang tepat dapat meningkatkan hasil belajar siswa. Nilai hasil belajar merupakan salah satu indikator yang bisa digunakan untuk mengukur keberhasilan belajar seseorang. Media pembelajaran disiapkan guru agar bisa memenuhi kebutuhan proses pembelajaran dan untuk mengetahui mengukur sejauh mana kemampuan siswa. Media memiliki berbagai fungsi dan bentuk yang beragam yang berguna untuk mengantarkan pesan yang tersirat saat menyampaikan pembelajaran (Sundayana 2018). Media dalam belajar berfungsi sebagai benda pendamping dimana berfungsi untuk menerjemahkan teori yang abstrak sehingga mudah untuk dipahami.

Geoboard adalah alat bantu dalam mengajarkan konsep geometri, seperti konsep bangun datar, konsep keliling bangun datar, dan menghitung serta menentukan luas sebuah bangun datar (Sundayana 2016). Geoboard dibuat dengan menggunakan peralatan berupa pensil, penggaris, gergaji, palu, ampelas dan kuas. Sedangkan bahan-bahan yang bisa digunakan adalah tripleks/papan, paku, lem kayu, cat/pilok, dan karet gelang

Berdasarkan hasil wawancara dengan guru kelas III SDN 101919 Kuala Namu menyatakan bahwa penyebab rendahnya hasil belajar siswa yaitu disebabkan karena siswa kurang aktif bertanya pada saat proses belajar mengajar, jarangnya menyelesaikan latihan yang diberikan, kurangnya alat dan bahan yang dibutuhkan saat mengajar, anak tidak fokus di dalam proses pembelajaran, siswa kurang termotivasi menyelesaikan tugas-tugas rumah, kurangnya interaksi sesama teman, anak-anak masih memandang pelajaran 
Cybernetics: Journal of Research and Educational Studies

Volume 2 Nomor 4, Oktober 2021

Halaman 103-113

matematika itu sulit dan diperoleh kondisi yang kurang mendukung sehingga mempengaruhi hasil belajar siswa. Kondisi tersebut diantaranya adalah minimnya pemanfaatan media pembelajaran sebagai sarana dalam menjelaskan materi pada mata pelajaran matematika yang menyebabkan siswa dominan tidak aktif saat pembelajaran berlangsung sehingga materi yang diajarkan sulit dimengerti oleh siswa. Hal inilah yang menyebabkan hasil belajar pada mata pelajaran matematika masih kurang. Selain itu, salah satu materi yang diajarkan di SDN 101919 Kuala Namu dalam pembelajaran matematika yaitu materi bangun datar dimana dalam melakukan pembelajaran ini guru masih sekedar menerangkan dan belum menerapkan penggunaan media pembelajaran yang tepat sebagai alat bantu dalam menjelaskan materi bangun datar. Hal inilah yang menyebabkan siswa cenderung kurang bersemangat dan tidak betah saat pembelajaran matematika berlangsung, mereka sering mengiginkan untuk cepat berganti ke pelajaran yang lain. Permasalahan lain juga muncul dari cara belajar siswa yang kurang memperhatikan penjelasan yang diberikan oleh guru sehingga ketika siswa diberikan pertanyaan seputar pembelajaran matematika yang telah diberikan sebelumnya siswa tidak mampu menjawab dengan benar karena telah lupa dengan apa yang telah dipelajarinya. Siswa juga menganggap pembelajaran matematika membosankan. Hal ini menunjukkan kurangnya perhatian siswa terhadap materi pembelajaran sehingga diperlukan media dalam proses pembelajaran agar siswa dapat mempelajari materi melalui bendabenda konkret yang dapat digunakan oleh siswa terutama pada materi bangun datar.

Keberhasilan siswa dalam belajar dapat dipengaruhi oleh factor dari dalam individu maupun luar individu. Banyak hal-hal yang mempengaruhi proses belajar mengajar matematika di sekolah, baik dari luar siswa atau lingkungan maupun dari dalam diri siswa itu sendiri. Ketidaksiapan factor eksternal dan internal akan memberi kendala dalam proses belajar siswa yang kemudian berimbas pada hasil belajar matematikanya.

Berdasarkan fenomena diatas maka peneliti dapat menyimpulkan bahwa dibutuhkannya perubahan dalam metode pembelajaran yang dimana dapat membuat siswa paham mengenai materi yang sedang di ajarkan oleh guru dengan bantuan media. Disini peneliti memberikan salah satu pemecahan masalah tersebut yaitu dengan menggunakan Media Pembelajaran Geoboard. Geoboard adalah alat bantu dalam mengajarkan konsep geometri, seperti konsep bangun datar, konsep keliling bangun datar, dan menghitung serta menentukan luas sebuah bangun datar. Adapun beberapa alasan yang merupakan pertimbangan pemilihan SD 101919 Kuala Namu sebagai tempat penelitian yaitu SD Negeri 101919 Kuala Namu belum pernah diterapkan penggunaan media 
geoboard pada pembelajaran matematika di nilai perlu diadakan penelitian untuk mengetahui pengaruh media geoboard terhadap hasil belajar siswa SD Negeri 101919 Kuala Namu. Maka dari itu, untuk mengetahui keadaan sebenarnya dari pengaruh penggunaan media pembelajaran geoboard terhadap hasil belajar matematika siswa pada materi bangun datar menggunakan media geoboard peneliti merasa perlu diadakan penelitian mengangkat judul "Pengaruh Penggunaan Media Pembelajaran Geoboard Terhadap Hasil Belajar Siswa Pada Keliling Dan Luas Bangun Datar kelas III SD"

\section{METODE PENELITIAN}

Penelitian ini merupakan penelitian kuantitatif, dan termasuk metode penelitian eksperimen. Desain penelitian yang digunakan quasi experimental design dengan bentuk nonequivalent control group design. Pada desain penelitian ini terdapat dua kelompok yaitu kelompok eksperimen dan kelompok kontrol. Kelompok eksperimen merupakan kelompok yang diberikan perlakuan dengan media papan berpaku dan kelompok kontrol merupakan kelompok yang tidak diberi perlakuan yang berfungsi sebagai pembanding.

Dalam penelitian ini, metode quasi experiment menggunakan bentuk desain Nonequivalent Control Group Design, di mana kelompok eksperimen (A) dan kelompok kontrol (B) tidak dipilih secara random. Pada dua kelompok tersebut, sama-sama dilakukan pretest dan posttest. Namun, hanya kelompok eksperimen saja yang di berikan-treatment atau perlakuan. Rencana penelitian ini adalah sebagai berikut:

\section{Tabel 1. Desain Penelitian}

\begin{tabular}{|c|c|c|c|}
\hline Kelompok & Pretest & Perlakuan & Posttest \\
\hline Eksperimen & $\mathrm{O}_{1}$ & $\mathrm{X}$ & $\mathrm{O}_{2}$ \\
\hline Kontrol & $\mathrm{O}_{3}$ & - & $\mathrm{O}_{4}$ \\
\hline
\end{tabular}

Keterangan :

$\mathrm{X}$ : perlakukan peneliti dengan menggunakan media pembelajaran berbasis video

$\mathrm{O}_{1}$ : Rerata skor pretest (tes awal) pada kelompok eksperimen

$\mathrm{O}_{2}$ : Rerata skor posttest (tes akhir) pada kelompok eksperimen

$\mathrm{O}_{3}$ : Rerata skor pretes (tes awal) pada kelompok control

$\mathrm{O}_{4}$ : Rerata skor posttest (tes akhir) pada kelompok kontrol

Nilai perlakuan $=\left(\mathrm{O}_{2}-\mathrm{O}_{1}\right)-\left(\mathrm{O}_{4}-\mathrm{O}_{3}\right)$ 
Cybernetics: Journal of Research and Educational Studies

Volume 2 Nomor 4, Oktober 2021

Halaman 103-113

\section{HASIL PENELITIAN DAN PEMBAHASAN}

Perbandingan data statistik hasil pretest kelas eksperimen dan kelas kontrol

Data statistik memudahkan peneliti dalam perhitungan uji prasyarat dan uji hipotesis nantinya. Data statistik pretest mengenai kedua kelompok berdasarkan perhitungan, sebagai berikut:

Tabel 2. Data Statistik Hasil Penelitian Pretest

\begin{tabular}{|l|c|c|}
\hline \multirow{2}{*}{ Data Statistik } & \multicolumn{2}{|c|}{ Pretest } \\
\cline { 2 - 3 } & Kelas eksperimen & Kelas Kontrol \\
\hline Nilai Terendah & 47 & 40 \\
\hline Nilai Tertinggi & 80 & 77 \\
\hline Rata-rata & 64,77 & 50.05 \\
\hline Median & 55,25 & 45,5 \\
\hline Modus & 64,7 & 47,5 \\
\hline Standar Deviasi & 8,28 & 11,05 \\
\hline Jumlah Siswa & 18 & 18 \\
\hline
\end{tabular}

Tabel di atas memperlihatkan hasil pretest kedua kelompok penelitian yang menunjukkan perbedaan. Nilai maksimum dan nilai minimum pretest yang diperoleh kelas ekperimen dan kelas kontrol menunjukkan perbedaan yaitu nilai maksimum 80 dan 77 sedangkan nilai minimum 47 dan 40. Selain itu, nilai ratarata kedua kelompok juga menunjukan perbedaan yaitu 61 untuk nilai rata-rata kelas eksperimen dan 53 untuk nilai rata-rata kelas kontrol dan selisih nilai ratarata kedua kelompok ialah sebesar 8 . Hasil ini menunjukkan bahwa perolehan rata-rata nilai pretest kelas ekperimen lebih tinggi dari pada kelas kontrol.

Perbandingan rata-rata nilai pretest kelas eksperimen dan kelas kontrol pada tabel diatas disajikan dalam diagram dibawah ini.

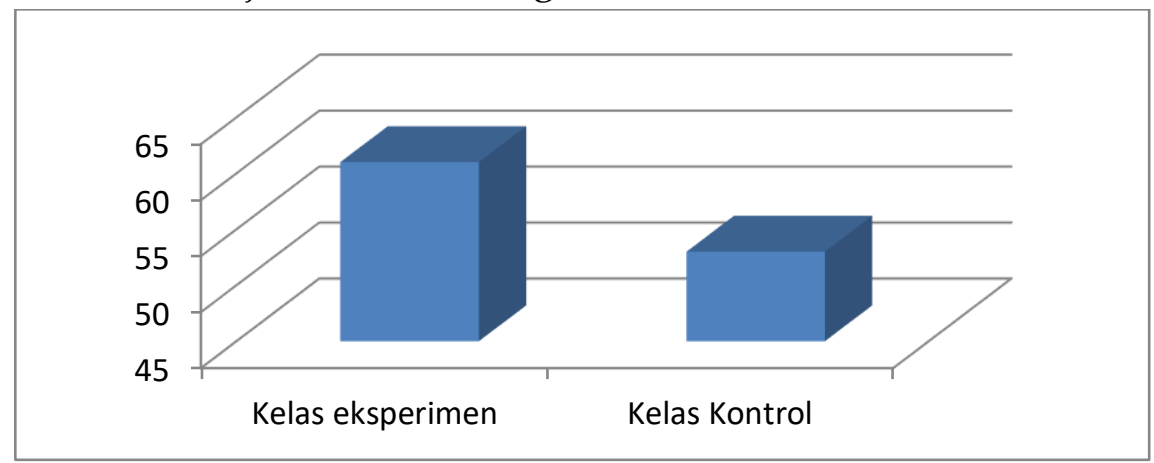

Gambar 1. Diagram Batang Distribusi Frekuensi Pretest Kelas Eksperimen dan Kontrol 
Cybernetics: Journal of Research and Educational Studies

Volume 2 Nomor 4, Oktober 2021

Halaman 103-113

Perbandingan data statistik hasil posttest kelompok eksperimen dan kelompok kontrol

Data statistik memudahkan peneliti dalam perhitungan uji prasyarat dan uji hipotesis nantinya. Data statistik posttest mengenai kedua kelompok berdasarkan perhitungan, sebagai berikut:

Tabel 3. Data Statistik Hasil Penelitian Posttest

\begin{tabular}{|l|c|c|}
\hline \multirow{2}{*}{ Data Statistik } & \multicolumn{2}{|c|}{ Posttest } \\
\cline { 2 - 3 } & $\begin{array}{c}\text { Kelompok } \\
\text { Eksperimen }\end{array}$ & $\begin{array}{c}\text { Kelompok } \\
\text { Kontrol }\end{array}$ \\
\hline Nilai Terendah & 67 & 60 \\
\hline Nilai Tertinggi & 100 & 97 \\
\hline Rata-rata & 85 & 75,05 \\
\hline Median & 78,19 & 65,5 \\
\hline Modus & 84,7 & 67,5 \\
\hline Standar Deviasi & 8,027 & 11,05 \\
\hline Jumlah Siswa & 18 & 18 \\
\hline
\end{tabular}

Tabel di atas memperlihatkan hasil posttest kedua kelompok penelitian yang menunjukkan perbedaan. Nilai maksimum dan nilai minimum posttest yang diperoleh kelompok eksperimen dan kelompok kontrol menunjukkan perbedaan yaitu nilai maksimum 100 dan 97 sedangkan nilai minimum 67 dan 60. Selain itu, nilai rata-rata kedua kelompok juga menunjukan perbedaan yaitu 85 untuk nilai rata-rata kelompok eksperimen dan 75,05 untuk nilai rata-rata kelompok kontrol dan selisih nilai rata-rata kedua kelompok ialah sebesar 9,95. Hasil ini menunjukkan bahwa perolehan nilai posttest kelompok eksperimen lebih tinggi dari pada kelompok kontrol.

\section{Pembahasan}

Berdasarkan hasil uji hipotesis penelitian ini menemukan bahwa hasil belajar siswa terhadap materi keliling dan luas bangun datar secara umum mempunyai pengaruh yang signifikan. Namun, pada kelas eksperimen hasil belajar siswa lebih tinggi dibandingkan kelas kontrol. Hal ini dikarenakan ada perbedaan perilaku yang diberikan kepada kedua kelas. Siswa pada kelas eksperimen lebih aktif dalam pembelajaran karena siswa dapat memahami mengenai materi yang sedang di ajarkan oleh guru dengan bantuan medi sehingga hasil yang dicapai menjadi lebih maksimal.

Kelas dengan pembelajaran menggunakan media geoboard ini sangat bermanfaat dalam mencapai tujuan pembelajaran. Hal ini sesuai dengan 
Cybernetics: Journal of Research and Educational Studies

Volume 2 Nomor 4, Oktober 2021

Halaman 103-113

pendapat Ratna (Listiyani, 2018: 18) bahwa media geoboard ini memiliki kelebihan:

(a) Siswa dapat membuat macam-macam bangun datar seperti persegi, persegi panjang, segitiga, trapesium, layanglayang dan jajar genjang, b) Bentuknya yang sederhana sehingga mudah dalam proses pembuatannya, c) Alat dan bahan mudah didapatkan, d) Terdapat unsur bermain dalam penggunaannya karena dapat membentuk macam-macam bangun datar.

Sebelum diberikan perlakuan, kedua kelas diuji normal dan homogennya untuk memilih kelas eksperimen dan kelas kontrol. Setelah diuji kedua kelas normal dan homogen, didapatkan kedua kelas normal dan homogen. Maka penentuan kelas eksperimen dan kelas kontrol secara acak, dengan ketentuan kelas yang terambil pertama adalah kelas ekeperimen dan kelas yang tidak terambil merupakan kelas kontrol.

Kelas eksperimen diberikan perlakuan dengan menggunakan media geoboard dan kelas kontrol tidak diberikan perlakuan. Kelas IIIA menggunakan media Geoboard dengan langkah menurut Sundayana (2013) yaitu :

(a) Letakkan Papan Berpaku di depan kelas, bisa digantung atau disandarkan benda lain. Papan Berpaku dilengkapi sejumlah karet gelang dengan warna-warna yang berbeda serta dilengkapi pula dengan kertas bertitik atau kertas berpetak.

(b) Guru mendemonstrasikan secara klasikal cara membentuk bangun datar.

(c) Kemudian masing-masing siswa membentuk bangun datar sesuai dengan kreativitas masing-masing.

(d) Siswa diminta menggambar hasil yang diperolehnya pada kertas bertitik atau kertas berpetak.

(e) Melalui tanya jawab guru mengenalkan arti keliling.

(f) Siswa menentukan keliling setiap bangun datar yang dia peroleh sebelumnya.

(g) Melalui tanya jawab guru mengenalkan arti luas bangun datar

(h) Siswa diminta untuk memperkirakan luas bangun datar yang telah dibuatnya.

Kedua kelas diberikan pre test dan post test, kemudian didapati siswa kelas eksperimen lebih aktif dibanding dengan kelas kontrol. Hal ini didukung oleh data yang tertera pada lampiran 20 dan 21, yang menunjukkan jumlah rata-rata kelas eksperimen lebih tinggi dibanding dengan jumlah rata-rata kelas kontrol. Rata-rata nilai kelas eksperimen lebih besar yaitu 85 daripada rata-rata nilai pada kelas kontrol yaitu 75,05. 
Cybernetics: Journal of Research and Educational Studies

Volume 2 Nomor 4, Oktober 2021

Halaman 103-113

Hal tersebut sesuai dengan hasil uji $\mathrm{t}$, dimana pada perhitungan uji $\mathrm{t}$ skor post test menunjukkan bahwa terdapat pengaruh yang signifikan. Skor post test kelas eksperimen dan kelas kontrol yang mana nilai thitung lebih dari $\mathrm{t}$ tabel $(2,9>2,02)$.

Dengan demikian dapat dinyatakan bahwa terdapat Pengaruh Penggunaan Media Pembelajaran Geoboard Terhadap Hasil Belajar Siswa Pada Keliling Dan Luas Bangun Datar kelas III SD.

\section{KESIMPULAN}

Berdasarkan hasil analisis data dapat disimpulkan bahwa penggunaan media pembelajaran geoboard berpengaruh yang signifikan terhadap hasil siswa pada keliling dan luas bangun datar. Hal ini ditunjukkan dari perolehan hasil perhitungan uji hipotesis posttest melalui uji-t pada taraf signifikansi 0,05, dimana $t_{\text {hitung }}>t_{\text {tabel }}$ yaitu 2,9 $>2,02$. Hasil ini diperkuat dengan pencapaian ratarata nilai siswa pada kelas eksperimen dengan nilai 85 sedangkan kelas kontrol memperoleh nilai 75,05 . Sehingga dapat dinyatakan bahwa penggunaan media pembelajaran geoboard merupakan solusi yang tepat untuk mengembangkan pembelajaran yang memberikan pengaruh baik terhadap hasil belajar siswa

\section{REFERENCE}

Afidah, \& Khairunnisa. 2014. Matematika Dasar. Jakarta : Rajawali Pers.

Arsyad, A. 2013. Media Pembelajaran. Jakarta : Rajawali Pers.

Daryanto. 2016. Media Pembelajaran. Yogyakarta : Gava Media.

Gultom, T. (2020). Penilaian Kinerja Guru Mengenai Profesionalisme Guru Di Smp Negeri 2 Pangaribuan Kabupaten Tapanuli Utara Tahun 2020. Journal Of Education And Teaching Learning (JETL), 2(3), 29-43. https://doi.org/10.51178/jetl.v2i3.66

Heruman. 2012. Model Pembelajaran Matematika di Sekolah Dasar. Bandung : PT. Remaja Rosdakarya.

Jafar, dkk. 2018. Penerapan Pendekatan Realistik Bersetting Pembelajaran Kooperatif Tipe TAI Untuk Meningkatkan Hasil Belajar Matematika Siswa Kelas V SD Inp 6/75 Manurungge Watampone Kab. Bone. JIKAP PGSD: Jurnal Ilmiah Ilmu Kependidikan, 2(2), 10

Johannes, J. (2021). Meningkatkan Hasil Belajar Siswa Menggunakan Model Pembelajaran Make A Match Pada Pelajaran IPA Materi Sifat-Sifat Cahaya Di Kelas V SD Negeri 060952 Medan Labuhan T.P. 2019/2020. Journal Of Education And Teaching Learning (JETL), 3(1), 50-61. https://doi.org/10.51178/jetl.v3i1.123 
Cybernetics: Journal of Research and Educational Studies

Volume 2 Nomor 4, Oktober 2021

Halaman 103-113

Lastrijanah, dkk. 2017. Pengaruh Media Pembelajaran Geoboard Terhadap Hasil Belajar Siswa. Didaktika Tauhidi: Jurnal Pendidikan Guru Sekolah Dasar, $4(2), 87-100$.

Listiyani, Dewi. 2018. Pengaruh Penggunaan Media Papan Berpaku Terhadap Hasil Belajar Siswa dalam Pembelajaran Matematika Kelas IV Gugus 01 Kota Bengkulu. Skripsi. Bengkulu: Program Studi Pendidikan Guru Sekolah Dasar Fakultas Keguruan dan Ilmu Pendidikan Universitas Bengkulu

Lumbangaol, T. (2020). Penerapan Strategi Pembelajaran Mind Mapping Untuk Meningkatkan Hasil Belajar Siswa Pada Materi “Teks Panjang" Mata Pelajaran Bahasa Indonesia di SDN 173346 Dolok Martumbur Kecamatan Muara Kelas IV T.P 2018/2019. Journal Of Education And Teaching Learning (JETL), 2(2), 27-34. https:/ / doi.org/10.51178/jetl.v2i2.62

Mashuri, S. 2019. Media Pembelajaran Matematika. Yogyakarta : Deeppublish.

Masitoh, \& Habudin. 2018. Pengembangan Media Pembelajaran Papan Berpaku Untuk Meningkatkan Pemahaman Konsep Luas Bangun Datar. Jurnal Kependidikan Dasar, 5(01), 50-60.

Meimulyani, Y., \& Caryoto. (2013). Media Pembelajaran Adaptif. Jakarta : PT. Luxima Metro Media.

Muamar Al Qadri, S. W. (2021). Pengaruh Home Visit Method Terhadap Hasil Belajar Luring di Masa Pandemi COVID-19 Pada Mata Pelajaran Al Qur'an Hadits (Studi Kasus Siswa Kelas VIII MTS Jam'iyah Mahmudiyah Tanjung Pura Langkat). Continuous Education: Journal of Science and Research, 2(1), 6171. https:/ / doi.org/10.51178/ce.v2i1.187

Purwanto. 2016. Evaluasi Hasil Belajar. Yogyakarta : Pustaka Pelajar.

Rusman, dkk. 2012. Pembelajaran Berbasis Teknologi Informasi dan Komunikasi. Jakarta : Rajawali Pers.

Rukmana, Indra. 2019. Peningkatan Hasil Belajar Materi Bangun Datar Menggunakan Papan Berpaku SD Negeri 2 Tlogopucang Tahun Ajaran 2017/2018. Jurnal Penelitian dalam Bidang Pendidikan dan Pengajaran, 13 (2), 188. Jurnal IMED, 3(2),11.

Yaumi, M. 2018. Media dan Teknologi Pembelajaran. Jakarta : Kencana.

Siti Rodi'ah, I. H. (2021). Strategi Pembelajaran Pendidikan Jasmani Berbantu Media Book Creator Digital Dalam Meningkatkan Kemampuan Motorik Kasar Siswa Pada Tingkat Sekolah Dasar. Continuous Education: Journal of Science and Research, 2(2), 23-35. https:/ / doi.org/10.51178/ce.v2i2.225

Sumantri, M. S. 2016. Strategi Pembelajaran. Jakarta : Rajawali Pers

Sundayana, R. 2018. Media Pembelajaran Matematika. Bandung : Alfabeta. 
Cybernetics: Journal of Research and Educational Studies

Volume 2 Nomor 4, Oktober 2021

Halaman 103-113

Tafonao, T. 2018. Peranan Media Pembelajaran Dalam Meningkatkan Minat Belajar Mahasiswa. Jurnal Komunikasi Pendidikan, 2(2), 103.

Upu, H., \& Minggi, I. 2019. Pengaruh Metode Diskusi dengan Alat Peraga Papan Berpaku terhadap Hasil Belajar Matematika Siswa

Sunhaji. 2014. Konsep Manajemen Kelas Dan Implikasinya Dalam Pembelajaran. Jurnal Kependidikan, 2(2), 46.

Pane, A. 2017. Belajar Dan Pembelajaran. Jurnal Kajian Ilmu-Ilmu Pembelajaran. 3(2), 340-350.

Sunhaji. 2014. Konsep Manajemen Kelas Dan Implikasinya Dalam Pembelajaran. Jurnal Kependidikan. 2(2), 32-33. 